\title{
Ciclo, crise e retomada da economia brasileira: avaliação macroeconômica do período 2004-2016 *
}

\author{
Marco Flávio da Cunha Resende ${ }^{* *, * * *}$ \\ Fábio Henrique Bittes Terra ${ }^{* * * *, * * * * * * * * * * *}$
}

\section{Resumo}

Com base no conceito de convenção em Keynes, este artigo analisa a queda cíclica em 2011-2014 e a recessão em 2015-2016 da economia brasileira a partir da relação entre as políticas macroeconômicas adotadas, as convenções constituídas e o investimento privado. Em linhas gerais, argumenta-se que contradições e falta de coordenação marcaram as políticas fiscal, cambial e monetária em 2011-2014, inviabilizando convenções otimistas e levando à fase descendente do ciclo. Em 2015-2016, a equivocada política econômica, a crise política e a Lava-Jato produziram o colapso da economia brasileira. Após isso, são apontadas as políticas macroeconômicas requeridas para a retomada sustentada da economia.

Palavras-chave: Convenções, Políticas macroeconômicas, Ciclo econômico brasileiro.

\section{Abstract}

A macroeconomic assessment of the 2004-2016 period in Brazil: the cycle, crisis and resuming growth of the economy

Based on Keynes' concept of convention, this article analyzes the cyclical decline of the Brazilian economy from 2011 to 2014 and the recession from 2015 to 2016 based on the relationship between the macroeconomic policies adopted, the conventions established and private investment. It is argued that contradictions and a lack of coordination marked fiscal, exchange rate and monetary policies in the 2011-2014 period, making optimistic conventions unfeasible and leading to the downward phase of the cycle. During 2015-2016, the mistaken economic policy, the political crisis and the Operation Car Wash (or Lava-Jato in Portuguese) led to the collapse of the Brazilian economy. Finally, the macroeconomic policies required for the sustained economic recovery are pointed out.

Keywords: Conventions, Macroeconomic policies, Brazilian economic cycle.

JEL E12, E50, E60, H30.

\section{Introdução}

$\mathrm{Na}$ abordagem Pós-Keynesiana, o investimento é a variável responsável pelo crescimento econômico no longo prazo, no entanto, seu retorno não pode ser conhecido a priori

*Artigo recebido em 10 de janeiro de 2019 e aprovado em 20 de dezembro de 2019.

${ }^{* *}$ Professor do Centro de Desenvolvimento e Planejamento Regional da Faculdade de Ciências Econômicas da Universidade Federal de Minas Gerais (Cedeplar. UFMG), Belo Horizonte, MG, Brasil. E-mail: resende@cedeplar.ufmg.br. ORCID: https://orcid.org/0000-0003-2069-2983.

${ }^{* * *}$ Pesquisador do Conselho Nacional de Desenvolvimento Científico e Tecnológico (CNPq), Brasília, DF, Brasil.

${ }^{* * * * *}$ Professor da Universidade Federal do ABC (UFABC), Santo André, SP, Brasil. E-mail: fhbterra@gmail.com. ORCID: https://orcid.org/0000-0002-2747-7744.

${ }^{* * * * *}$ Professor do Programa de Pós-Graduação em Economia da Universidade Federal de Uberlândia (PPGE. UFU), Uberlândia, MG, Brasil.

${ }^{* * * * * * *}$ Pesquisador do CNPq, a quem agradece o suporte financeiro para esta pesquisa. 
nem mesmo em termos probabilísticos, devido à incerteza fundamental, isto é, por conta da incapacidade de os agentes saberem o que o futuro trará. Por existir incerteza, os agentes têm que construir expectativas sobre o futuro para decidirem a alocação de sua riqueza entre diversos ativos alternativos, inclusive os bens de capital. Como no contexto da incerteza fundamental o cálculo atuarial perfeito não é possível, os agentes formam suas expectativas em um processo que em muito se baseia em convenções, que são crenças compartilhadas, capazes de ancorar as expectativas dos indivíduos. Porém, elas são, ao mesmo tempo, voláteis, pois nada mais são do que crenças partilhadas pelos agentes (Keynes, 1973; Carvalho, 2014).

Para a formação de convenções favoráveis ao investimento privado, a participação do setor público é imprescindível. Atuando de modo cooperativo e complementar ao setor privado, as ações e políticas do governo devem ensejar confiança no retorno dos investimentos, levando os agentes a adquirirem capital fixo em detrimento de ativos financeiros líquidos, que podem ser preferíveis quando há muita incerteza. Neste contexto, as políticas macroeconômicas são cruciais para influenciar as expectativas e moldar convenções otimistas sobre o futuro.

O objetivo deste artigo é analisar a crise recente da economia brasileira a partir da relação entre convenções, as decisões de investimento privado e as políticas macroeconômicas adotadas, sobretudo após $2011^{1}$. Após isso, ainda se baseando no conceito de convenção em Keynes, serão apontadas as políticas fiscal, cambial e monetária requeridas para a retomada sustentada da economia do Brasil. O recorte temporal do artigo compreende o período 20042016, com ênfase na fase descendente do ciclo, que se finalizou na profunda recessão de 20152016.

Além desta introdução e da conclusão, este artigo se divide em mais quatro seções. Na próxima seção o conceito de convenção e as prescrições Pós-Keynesianas de política macroeconômica são apresentados. Com base no conceito de convenções e na política econômica prescrita pelos Pós-Keynesianos, examinam-se na seção dois as causas da fase descendente do ciclo da economia brasileira. A seção três analisa o Brasil no caminho para sua mais grave recessão, 2014-2016. Na seção quatro são, então, sugeridas alternativas de políticas macroeconômicas que seriam adequadas para a retomada do crescimento sustentado da economia brasileira.

\section{Convenções e políticas macroeconômicas}

Na Escola Pós-Keynesiana, a incerteza fundamental é elemento central, significando que é impossível terem-se todos os elementos necessários ao conhecimento do resultado futuro de uma decisão tomada no presente. Há duas naturezas de incerteza, a epistemológica, que se

(1) Há na literatura diversas interpretações sobre as causas da recente crise da economia brasileira. Ver, por exemplo, Prates et al. (2014), Serrano e Summa (2015) e Carvalho (2018). Contudo, o objetivo deste artigo, que é seu traço distintivo em relação às citadas referências, é focar a relação entre as políticas macroeconômicas adotadas, as convenções constituídas e as decisões de investimento privado para o período 2004-2016, considerando que, muitas vezes, estas diversas interpretações mencionadas são semelhantes ou complementares à elaborada neste artigo. 
refere à forma pela qual o sujeito conhece, inerentemente desprovido de todos os dados necessários ao conhecimento completo; e a ambiental ou ontológica, concernente à realidade externa ao indivíduo, que é incapaz de ser plenamente conhecida por estar em incessante transformação.

Portanto, a incerteza existe porque não há informação plena para a tomada de decisão, em particular aquelas atreladas a longos horizontes temporais, visto que este tempo ainda está por ser construído, impedindo o cálculo atuarial certo e deixando ao decisor apenas expectativas de um resultado. Desta forma, a incerteza é um fenômeno cuja probabilidade não pode ser calculada, deixando as pessoas ignorantes sobre o futuro (Ferrari-Filho e Conceição, 2005). Neste sentido, o agente busca segurança (o que, diga-se de passagem, não quer dizer certeza) contra a sua ignorância em relação ao futuro ancorando-se em mimetizar os outros agentes: eis o comportamento convencional, resultado da tentativa dos agentes de obter proteção diante da incerteza (Carvalho, 2015).

Assim, o futuro não pode ser predito e, por exemplo, decisões de gasto, em particular de investimento, podem ser adiadas por tempo indeterminado quando vigora a preferência pela liquidez. Quando a expectativa de um futuro desanimador ganha a mentalidade coletiva tornando-se uma crença compartilhada, isto é, uma convenção, tem-se a causa das crises para Keynes (1973): uma inflexão das expectativas de retorno dos investimentos produtivos. Então, arrefece-se o processo de acumulação de capital e, logo, a trajetória de longo prazo da economia. Portanto, não há a neutralidade da moeda, mesmo no longo prazo, pois convenções que guiam uma maior preferência pela liquidez alteram o ritmo dos investimentos no presente e, logo, o estoque de capital futuro. Assim, diferente do que postulam as "expectativas racionais" que baseiam a tomada de decisão para o mainstream econômico, a relação entre incerteza e convenções tanto é a causa das crises econômicas quanto inviabiliza a existência de mecanismos automáticos de mercado que corrijam desvios da economia em relação a uma trajetória ótima de longo prazo.

Quanto maior o horizonte temporal associado à determinada decisão de gasto, maior será a incerteza neste processo. Logo, decisões de investimento são as mais voláteis, pois estão atreladas a expectativas com maior possibilidade de frustração. Todavia, o investimento é a variável chave que determina a dinâmica e os ciclos econômicos (Keynes, 1973). Como os eventos econômicos futuros não podem ser calculados em termos estatísticos, os investidores se guiam baseados em suas próprias expectativas, sobre as quais convenções importam. Consequentemente, a trajetória futura da economia não está dada e será resultado do conjunto de decisões de gasto dos agentes no presente, sendo que eles não possuem as informações relevantes para assumirem "expectativas racionais" e um comportamento maximizador (Carvalho, 2015).

Portanto, o investimento em capital fixo requer o animal spirits empresarial, isto é, sua disposição em enfrentar o desconhecido a partir, por um lado, da expectativa otimista quanto ao retorno futuro do empreendimento e, por outro lado, do grau de confiança detido nessa 
expectativa (Keynes, 1973). Como antes dito, na economia monetária as expectativas em muito se formam baseadas em convenções. Estas não eliminam a incerteza, mas podem ancorar as decisões de investimento quando ensejam confiança nas expectativas. Assim se confere estabilidade à economia enquanto for possível "acreditar que o estado atual dos negócios continuará indefinidamente" - isto é, que determinada convenção seguirá prevalecendo (Keynes, 1973, p. 152).

Mas, o que se deve entender por convenções? Na literatura Pós-Keynesiana as convenções referem-se a uma regra coletiva de comportamento, não-determinística, de caráter mimético e baseada em expectativas formadas a partir da interação entre os agentes (Dequech, 1999; Dow, 2010; Davis, 1997). À guisa de uma síntese do conceito, tenha-se convenção como definem Modenesi et al. (2011) e Carvalho (2014): uma crença compartilhada entre os agentes, que entra no cálculo incerto de futuro feito por eles e cujas raízes detêm elevada intersubjetividade.

Por sua vez, diversos fatores influenciam e moldam as convenções, e consequentemente as expectativas, quanto ao futuro da economia. Dentre estes, citem-se as políticas econômicas, instituições, mudanças tecnológicas, noticiário - e, por sinal, no conectado mundo atual, entram em cena convenções moldadas por fake news. Em termos de política econômica, cabe ao governo, a bem de construir convenções e coordenar as expectativas dos agentes, emitir os sinais do que ele espera e deseja do futuro, algo que o mercado é incapaz de construir e coordenar sozinho. O papel do governo é convencer os agentes de que suas políticas são adequadas para estimular o lucro e, portanto, o investimento privado e o crescimento econômico, ensejando expectativas de um ambiente econômico seguro e estável.

Portanto, a convenção é influenciada pelo Estado e deve ser compreendida como "um instrumento de coordenação de expectativas, de informação a cada um do que outros esperam resultar de um dado estímulo" (Carvalho, 2014, p. 257). A capacidade estatal de afetar as convenções decorre de suas várias fontes de poder, tais quais as de: (i) emitir moeda exógena e controlar a criação de moeda endógena; (ii) estipular e arrecadar impostos; (iii) realizar amplo escopo de políticas; (iv) estabelecer leis, fiscalizar o cumprimento delas, e afetar a estrutura institucional da sociedade; (v) ter amplo aparato administrativo à sua disposição. Por isso Keynes (1980a, 1980b) apontava que a realização de políticas econômicas coordenadas ao estímulo do investimento privado e à consecução da estabilização automática dos ciclos econômicos era uma das ações fundamentais do Estado.

Quais são, em linhas gerais, as prescrições de política econômica feitas por Keynes e seus intérpretes pós-keynesianos? No caso da política fiscal, o orçamento público deve ser dividido em dois: o corrente e o de capital. $\mathrm{O}$ orçamento de capital deve estar ligado ao plano de investimentos públicos de médio/longo prazo, pré-anunciado, de caráter contracíclico, visando coordenar a formação de expectativas e estabilizar o ciclo econômico, evitando booms e bursts. O investimento público deve ser feito ou em parceria direta com o investimento 
privado, ou de forma complementar a este a bem de se buscar um efeito crowding-in. O investimento público reduz custos de produção e aumenta a produtividade quando voltado para infraestrutura (inclusive com equipamento de educação e saúde), além de, em nível macroeconômico, gerar melhorias na distribuição da renda e redução da pobreza (Aschauer, 1989; Rozas; Sanches, 2004; Calderón; Sérven, 2004). Se crível, tal plano sustenta expectativas otimistas sobre um nível da demanda agregada futura e retorno dos investimentos, fomentando convenções otimistas. Por sua vez, o orçamento corrente é o que custeia a oferta de serviços públicos à população, como defesa nacional, previdência social, segurança nacional, entre outros.

O orçamento público (corrente e de capital) deve ser intertemporalmente equilibrado, e superávits do orçamento de capital na fase de boom devem financiar os déficits na desaceleração econômica, tornando desnecessário aumentar a dívida pública para este fím. A preocupação de Keynes com um orçamento equilibrado pode ser vista em suas próprias palavras: "decididamente (...) [não se deve permitir] que se confunda a ideia fundamental do orçamento de capital com o particular - e um tanto quanto desesperado - expediente do déficit" (1980a, p. 353-354). Déficits orçamentários somente devem ocorrer se "o volume de investimentos planejados falhar" (p. 352). Apenas nestas condições, "o equilíbrio poderá ser encontrado por meio do desequilíbrio (...) do orçamento corrente. Admitidamente isto deverá ser um último recurso, que deverá entrar em jogo apenas se a maquinaria do orçamento de capital se quebrar" (Keynes, 1980, p. 352).

Tal preocupação é também partilhada por Minsky, que aponta que déficits podem ocorrer, porém devem ser temporários, "qualquer desvio de um orçamento público que está equilibrado ou em superávit precisa ser compreendido como transitório" (1986, p. 303). A razão para tais preocupações decorre da forma pela qual o déficit pode, se mal comunicado e incapaz de construir convenções sobre suas razões atuais e equilíbrio futuro, implicar prêmio de risco crescente para seu financiamento e, em última instância, fuga da dívida pública, pois, conforme ressalta Minsky (1986, p. 302) "não há nada de especial na dívida do governo, e uma fuga da dívida do governo pode ocorrer”. Com efeito, na ausência de cálculo atuarial certo, expectativas otimistas e convenções que as ancorem tornam-se centrais para empresários irem adiante com seus investimentos, mas uma trajetória de dívida pública que pareça descontrolada pode impactar expectativas e convenções. Logo, o próprio Keynes chama a atenção para o desejável zelo com o equilíbrio fiscal. Minsky (1986) também deixa clara a importância de um orçamento público equilibrado no contexto das economias monetárias. ${ }^{2}$

(2) Sobre a relevância do equilíbrio fiscal do Estado, Terra (2019, p. 66) argumenta: "Por fim, as finanças públicas são uma âncora às expectativas, pois funcionam como uma demanda persistente com a qual os empresários contam e ainda, se bem organizadas e equilibradas, como Keynes (1980) propõe, constroem confiança nos agentes sobre os rumos futuros da política econômica e da dívida pública. Se as expectativas podem ser por demais instáveis, Keynes $(1964,1980,1982)$ deixa claro que a política econômica precisa ser justamente o contrário: a mais estável possível, assim funcionando como o apoio mais certo com que conta o empresário". 
A política fiscal deve ainda implementar reformas institucionais, particularmente afetando a distribuição da renda, através de política tributária progressiva e políticas de renda, visando a estabilidade social e o aumento da propensão a consumir da sociedade. Uma política fiscal com estas características pretende-se capaz de guiar os agentes em meio à incerteza, sinalizando para o aumento da competitividade da economia e dos lucros. Ela é um instrumento de coordenação de expectativas privadas, que contribui para a emergência de convenção otimista, necessária para estimular o investimento privado. Como consequência, haverá um ambiente com maior demanda agregada tanto na forma de maiores investimentos bem como de maior consumo.

No que se refere à política monetária, seu objetivo é afetar a curva de rendimentos (juros) do sistema financeiro para estimular o investimento privado. Nos termos de Keynes (1973), a política monetária marca via operações de mercado aberto sua taxa de juros e busca afetar o motivo especulação de demanda por moeda e, assim, influenciar a oferta e demanda por moeda no sistema financeiro, influenciando a taxa de juros. Por isso, para Keynes (1973), a taxa de juros é um fenômeno convencional. Desta forma, a curva de juros depende da resposta dos agentes à política monetária. Se eles compartilham a convenção de que o Banco Central (BC) terá êxito em reduzir e manter baixa a taxa de juros básica, eles esperarão que o preço de mercado dos títulos prefixados subirá, e os comprarão antes disso, rebaixando a curva de juros. Contudo, se prevalecer a convenção de que o $\mathrm{BC}$ não será exitoso, o rebaixamento da curva de juros não ocorre, pois os agentes se manterão líquidos, especulando pela queda dos preços dos títulos e o consequente aumento das taxas de juros. Assim, quando o BC muda a taxa de juros básica sem considerar as expectativas dos agentes no mercado financeiro, sua política monetária pode ser ineficaz. Nas palavras de Keynes, "A autoridade monetária controla, com facilidade, a taxa de juros de curto prazo [...] Mas a taxa a longo prazo pode mostrar-se mais recalcitrante no momento em que caia a um nível que [...] a opinião abalizada considere 'inseguro' [...] uma política monetária que chega à opinião pública como sendo caracteristicamente experimental ou facilmente passível de mudança pode falhar [...]. A mesma política [...] pode ser facilmente bem-sucedida se ela aparece à opinião pública como razoável e praticável, baseada em convicção sólida [...]” (1973, p. 203).

Além das operações de open market, outro instrumento de política monetária é a regulação, que são legislações formais que delimitam o comportamento individual e, assim, definem o que se pode fazer nas transações do mercado financeiro. Leis e regras no mercado financeiro devem ser estáveis, o que é requisito para a formação de convenção otimista, pois os agentes a todo tempo as consideram para realizar seus negócios.

Por sua vez, para a política cambial Keynes sugeriu um regime de taxa de câmbio administrada e estável que, contudo, pode ser alterada conforme as circunstâncias (FerrariFilho, 2006). A estabilidade da taxa de câmbio é requerida para dar previsibilidade às expectativas de retorno dos investimentos, sejam aqueles ligados ao setor exportador, ou sejam domésticos, tanto os que compete com importados ou os que usam importados como insumo básico. Câmbio estável também aumenta a estabilidade do salário real em moeda externa, 
facilitando o cálculo do nível da demanda doméstica, necessário para a formação de expectativas dos empresários.

Nesta lógica, a taxa de juros não deve ser usada para atrair capitais externos e afetar a taxa de câmbio - que, por sinal, não deve atuar como âncora nominal, pois tal política eleva a taxa de juros, aumenta a sua volatilidade e reduz a competitividade da produção doméstica por meio da apreciação cambial, inibindo o investimento. Não obstante, no contexto da hierarquia de moedas do sistema financeiro internacional, as taxas de juros dos países cujas moedas são inconversíveis são mais elevadas, restringindo a autonomia de política monetária do BC (Fritz et al., 2016). Devido a estes fatores, autores Pós-Keynesianos sugerem controle de capitais, sobretudo sobre fluxos de capital especulativo de curto prazo, que afetam a taxa de juros e retiram autonomia da política monetária para lidar com problemas domésticos.

Finalmente, as políticas fiscal, monetária e cambial devem ser articuladas e mostrar coerência entre si para que o governo tenha êxito na coordenação das expectativas privadas. Os agentes têm que acreditar não apenas que as políticas praticadas são adequadas ao crescimento econômico, mas, sobretudo, precisam ter confiança de que os demais agentes estão convencidos disso também (Carvalho, 2014). A trajetória futura da economia será o resultado das decisões presentes de gasto, adotadas segundo as expectativas dos agentes em geral. Este é o requisito para o surgimento de uma crença compartilhada, isto é, de uma convenção, que imprimirá otimismo aos agentes, levando-os a investir. Neste sentido, a próxima seção analisa a fase descendente do ciclo econômico brasileiro de 2004-16, qual seja, os anos 2011-16, e sua aguda recessão experimentada em 2015-16, tendo como base as políticas fiscal, cambial e monetária então praticadas e o conceito de convenção em Keynes.

\section{Política macroeconômica, convenções e o ciclo da economia brasileira de 2004-2016}

Entre 2004 e 2010, a economia brasileira viveu a fase de boom do ciclo em análise, com crescimento médio anual de 4,5\%. Entre 2011 e 2014, esta taxa caiu para 2,4\% e no biênio 2015-16 a economia mergulhou em profunda recessão, com crescimento médio anual negativo de 3,5\% (BCB, 2018). Embora o investimento seja a variável responsável pela dinâmica econômica no longo prazo, o crescimento de 2004-2010 não foi puxado principalmente por ele, mas sim pela conjunção de estímulos advindos de um cenário externo altamente benigno e da expansão do consumo doméstico, em um contexto de elevada capacidade ociosa da economia, decorrente de vários eventos sucessivos, como a crise cambial de 1999, o "apagão" de 2001 e o "Efeito-Lula" nas eleições de 2002. A política de estímulo ao consumo também teve seu papel na recuperação econômica após 2003: políticas sociais de valorização real do salário mínimo, de transferência de renda (sobretudo o Bolsa Família), a apreciação contínua da taxa de câmbio real que confere ganhos reais aos salários, e o grande aumento da relação crédito/PIB, que passou de 25\% em 2003 para 40\% em 2008 (BCB, 2018) 3 .

(3) Estas políticas sociais não apenas estimularam diretamente o consumo, como também contribuíram para a redução da pobreza e a melhoria da distribuição da renda, que elevam a propensão a consumir da sociedade (Keynes, 1973). 
O investimento cresceu durante a expansão cíclica da economia, porém, partindo de um patamar extremamente baixo e sem força suficiente para explicar o desempenho da economia em 2004-10. A taxa de investimento saiu de 17,3\% do PIB em 2004, alcançou 18\% em 2007 e 20,5\% em 2010, porém foi sempre inferior a 19,5\% entre 2003-09 (IBGE, 2018). Todavia, para se alcançar um crescimento sustentado da economia brasileira de 4,5\% ao ano, a taxa de investimento deve ser de $24 \%$ do PIB (Oreiro, 2013).

$\mathrm{O}$ crescimento daquele período foi export-and-consumption-led, viabilizado por elevada capacidade ociosa: na indústria de transformação, a utilização da capacidade produtiva era de 79,7\% em 2003, e em 2008, 83\% (Ipeadata, 2017). Porém, o crescimento da economia foi interrompido em 2009 pela crise financeira mundial, que repôs parte da capacidade ociosa. Uma série de políticas contracíclicas ${ }^{4}$ foram adotadas do final de 2008 , possibilitando um expressivo crescimento em 2010, ainda em um contexto de baixo uso da capacidade produtiva: $80,6 \%$ em 2009 e 83,3\% em 2010 (Ipeadata, 2017). Não obstante, o crescimento foi acompanhado do aumento do investimento, que alcançou 20,5\% do PIB em 2010 (Ipeadata, 2017), contudo, ainda insuficiente para garantir o crescimento sustentado da economia.

Em 2011 teve início a fase descendente do ciclo: o crescimento caiu para $4 \%$ e foi se reduzindo até alcançar 0,5\% em 2014 e -3,5\% em 2015 e em 2016. Tendo como pano de fundo este panorama do ciclo econômico, analisar-se-á a seguir a relação entre as políticas macroeconômicas adotadas a partir de 2011, as convenções formadas, o downturn e a recessão econômica brasileira.

\subsection{Inconsistências das políticas macroeconômicas e sociais e a fase descendente do ciclo}

O primeiro governo Dilma Rousseff iniciou-se em 2011 e um caráter contraditório marcou sua política macroeconômica, que ficou conhecida como Nova Matriz Econômica (NME). Em 2014 Dilma foi reeleita presidente e mudou radicalmente a política econômica corroborando que a experiência 2011-14 não havia sido bem-sucedida. Serão feitas, a seguir, duas análises. A primeira compreende os impactos econômicos das políticas fiscal, cambial e monetária da NME no período 2011-14. A outra analisa o biênio recessivo 2015-16.

\subsubsection{Política fiscal}

Entre 2011-14 o bom cenário externo do miniciclo das commodities de 2010 cedeu. O valor das exportações brasileiras em dólares correntes, que subiu quase continuamente entre 2004-11, caiu 12\% entre 2011-14. Com a ausência do drive externo, ficou a cargo da política econômica doméstica estimular o crescimento, via incentivos ao investimento privado. Parcela relevante deste estímulo recaiu à política fiscal.

Assim, entre 2011 e 2013 o superávit primário do setor público foi reduzido de 2,89\% do PIB para 1,74\% (Ipeadata, 2017). O governo, como medida contracíclica, desonerou a folha de salários, isentou impostos de diversos setores (automotivo, construção civil, bens de capital,

(4) Sobre estas políticas, ver Arestis e Terra (2015). 
cesta básica, etc.), promoveu a redução da tarifa de energia elétrica e mudou as regras do plano de concessões de ferrovias e rodovias. Tais medidas foram aplicadas inicialmente para alguns setores, difundindo-se em seguida para outros, de maneira confusa e não criteriosa. Sem consistência setorial e, ademais, sem apresentar um planejamento de ações coordenadas e horizontalidade de atendimento setorial, a difusão das medidas fiscais, ao invés de incentivar, inibiu convenções otimistas.

Em 2011, o governo, ao mesmo tempo em que lançava a segunda fase do Programa de Aceleração do Crescimento (PAC 2), visando promover o investimento público, implementou forte contração fiscal, baseada na queda nominal dos seus investimentos, inclusive das empresas estatais. Ele emitia, portanto, sinais contraditórios - naquele ano o governo ainda reduziu o crescimento do seu gasto real de consumo e, pela primeira vez desde 1994, não concedeu aumento real do salário mínimo (Serrano; Summa, 2015).

O PAC 2 era um plano de quatro anos de investimentos públicos, principalmente em infraestrutura. Tinha características de uma política fiscal Keynesiana: um plano de investimentos públicos, previamente anunciado à sociedade, com duração de médio prazo e que poderia ser usado de forma contracíclica, pois seus dispêndios não contavam para o cálculo do resultado primário. Esperava-se que o PAC estimulasse expectativas otimistas, encorajando investimentos privados, porém, paradoxalmente, iniciou-se em ano de forte contração fiscal.

Ademais, o Programa teve falhas ligadas a um orçamento público engessado, à incapacidade de gestão do Estado, à institucionalidade e legislação vigentes no país, que impediram a execução de muitas de suas obras, fazendo o investimento público permanecer estacionado em torno de $2,5 \%$ do PIB. Além da estagnação do investimento público, não se organizou um orçamento de capital capaz de atuar de modo contracíclico, caso fosse necessário. Esses fatores impediram o PAC de coordenar as expectativas e estratégias de investimento privado e, assim, estimular uma convenção na direção dos sinais que o Programa se propunha: acelerar o crescimento.

A política fiscal emitiu sinais contraditórios. Ela perseguiu superávits primários, embora decrescentes, concomitantemente com a implantação de extensa política de isenção tributária que, por seu turno, reduzia as receitas do Estado e prejudicava o seu financiamento. Ademais, as despesas financeiras do governo central eram elevadas e crescentes pós-2013, alcançando 4,5\% do PIB em 2014 (BCB, 2018), devido à elevação da taxa de juros básica e ao crescente endividamento público brasileiro neste período. Além disso, à queda de receitas pelas desonerações somou-se uma menor arrecadação que veio com o downturn da economia. Assim, as finanças públicas eram tidas por confusas e inspiravam convenções pessimistas nos agentes sobre seu comportamento e sustentabilidade futuros ${ }^{5}$.

(5) Este desgaste das convenções foi reforçado por artifícios que causavam desconfiança: cite-se a chamada "contabilidade criativa", além do anúncio de metas irrealistas de expansão do PIB, das receitas e de superávit primário (Terra et al., 2018, p. 52). 
Visto que o investimento público não cresceu e o investimento privado não reagiu à política de isenção tributária, a atividade econômica, que não mais recebia o impulso das exportações, perdeu ainda mais força - devido ao arrefecimento da demanda agregada, mesmo as políticas de recuperação das margens de lucro no setor privado não estimularam novos investimentos (Serrano; Summa, 2015). De fato, o investimento agregado teve aumentos trimestrais menores a partir de 2012, com alguma recuperação em 2013, mas que se tornaram negativos em 2014, quando a variação média trimestral foi -1,47\% (IBGE, 2017).

\subsubsection{Política cambial}

A taxa de câmbio real (TCR) manteve-se apreciada durante o período 2011-14, e mesmo a desvalorização do câmbio nominal iniciada em 2012 foi insuficiente para compensar a longa apreciação do período anterior, como apresenta o Gráfico 1. A apreciação da TCR (ou seja, a queda dos preços dos bens tradables em relação aos non-tradables) leva à redução dos lucros no setor de tradables (indústria e agricultura, grosso modo), inibindo os seus planos de expansão de investimentos. No caso da agricultura e da indústria extrativa, esse problema foi superado entre 2003-12 pelas suas vantagens comparativas e aumento dos preços internacionais de commodities minerais e agrícolas. Porém, a apreciação cambial, somada ao arrefecimento do crescimento da demanda agregada, inibiu os investimentos na indústria de transformação que, por sua vez, é o motor do crescimento a longo prazo, por ser a principal responsável pelo progresso tecnológico e ganho de produtividade da economia (Gala, 2008; Bresser-Pereira et al., 2015).

Gráfico 1

Taxa de câmbio efetiva real, Brasil, 2002-2016 (mensal, em índice, $2010=100$ )

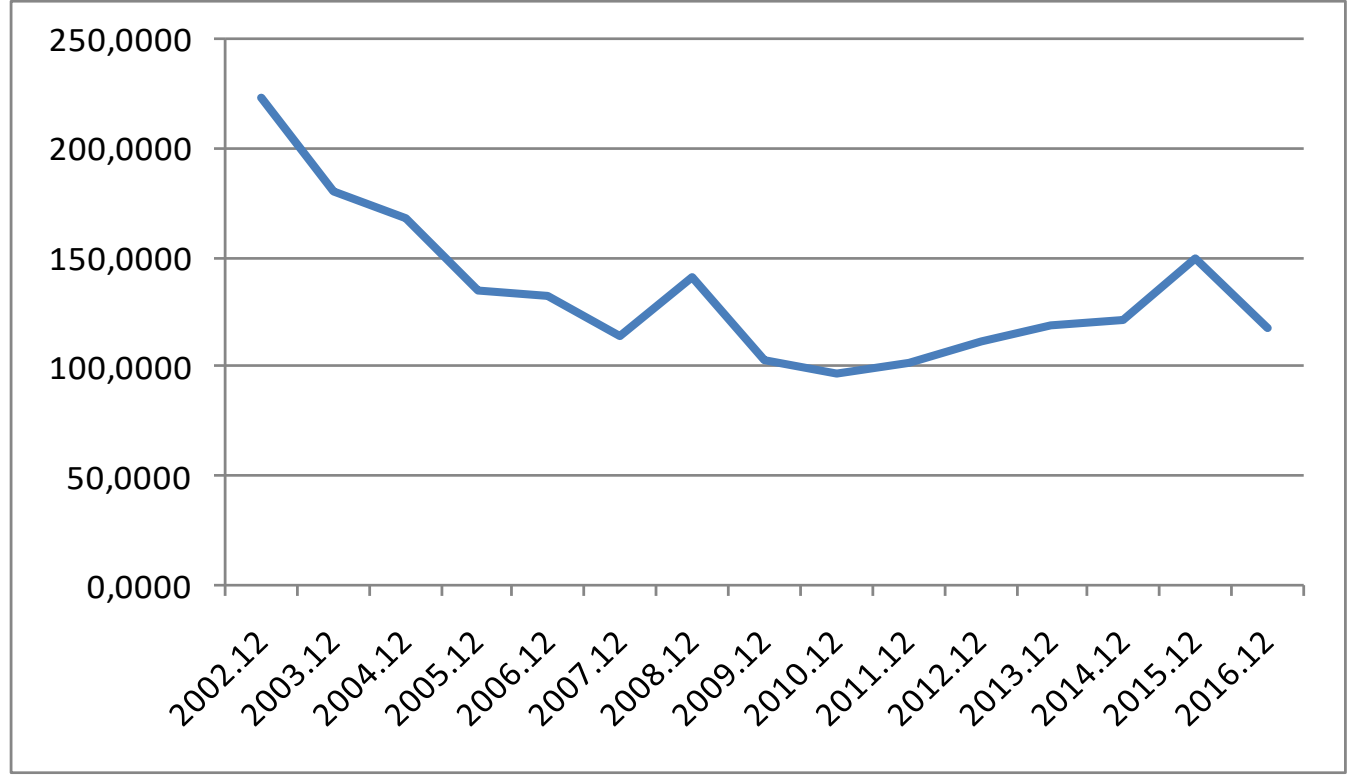

Fonte: Ipeadata (2017). 
Houve no Brasil, entre 2011 e 2014, uma inconsistência das políticas cambial com as de distribuição da renda e aumento do consumo doméstico. A TCR apreciada conferia poder aquisitivo aos salários no curto prazo que, junto com a política de transferência de renda, de aumento real do salário mínimo e de expansão do crédito, estimulava o consumo, porém, parte dele, sobretudo de tradeables, era atendido por importações. Assim, paradoxalmente, toda esta política de estímulo ao consumo colocava um teto para o investimento na indústria de transformação cuja dinâmica, por sua vez, é condição para ganhos de produtividade e crescimento da oferta agregada no longo prazo. A taxa máxima de investimento no período, 20,9\% (Ipeadata, 2017), verificou-se em 2013, mas ainda em nível insuficiente para garantir o crescimento sustentado da economia, de acordo com cálculos de Oreiro (2013).

Com o teto para o aumento do investimento decorrente do câmbio apreciado, e com crescente importação de bens de consumo, houve reprimarização da estrutura produtiva e da pauta de exportações da economia brasileira (Rossi; Mello, 2016). Isso comprometeu os ganhos de produtividade na economia e, assim, imprimiu uma barreira aos aumentos reais de salários a longo prazo, contrariando os próprios objetivos da política social. Ademais, sem aumento do investimento, a oferta agregada só poderia acompanhar o crescimento da demanda agregada enquanto houvesse capacidade ociosa: quando ela se esgotasse, o aumento da demanda seria satisfeito pelo aumento das importações, prejudicando o saldo em transações correntes e a geração de empregos, uma incoerência com os objetivos da política social. Ajudado pela apreciação da TCR, o déficit em transações correntes pulou de 2,9\% do PIB em 2011 para 4,2\% em 2014 (BCB, 2018), elevando a fragilidade externa da economia. A percepção destas inconsistências de políticas pelos agentes não permitiu o surgimento de convenção otimista, capaz de promover um cenário de crescimento puxado pelo aumento da taxa de investimento ${ }^{6}$.

No primeiro ano do governo Dilma, o acúmulo de reservas internacionais, controles de capitais e operações de swaps cambiais foram ampliados visando reverter a trajetória de apreciação da TCR (Prates et al., 2014, p. 59-60). Com essas ações, ela se depreciou no período, também ajudada pela redução da taxa básica de juros e pela deterioração do cenário externo com a crise do Euro. Mas, a desvalorização do câmbio nominal de 23,3\% entre 2011 e 2013 foi insuficiente para compensar sua apreciação de 56,8\% do período 2003-10 (Ipeadata, 2017) e estimular as exportações e o investimento privado - em termos da TCR tal insuficiência fica ainda maior, por causa da inflação do período.

No que se refere aos controles de capitais, em 2011 o governo implementou imposto sobre fluxos de capitais de curto prazo (IOF sobre posições vendidas no mercado de derivativos de câmbio), em seguida aumentou este imposto e depois o eliminou. Tudo isto apenas entre 2011 e 2012. Estas decisões sugeriam que as ações do governo eram temporárias e sem

(6) Tais inconsistências estavam presentes também na fase ascendente do ciclo, 2004-2010. Contudo, elas não impediram o vigoroso crescimento da economia naquele período: o estímulo vindo do exterior (demanda externa e termos de troca) e os níveis médios da TCR e da capacidade ociosa da economia eram superiores aos do período 2011-2014, e o crédito bancário apresentava baixos níveis. Assim, havia espaço para o aumento da relação crédito/PIB, algo com sinais de esgotamento após 2011 (Serrano; Summa, 2015, p. 21). 
planejamento, contribuindo para a perda de confiança na política cambial, ou seja, mais um elemento a contribuir para construir uma convenção pessimista.

A estratégia de acúmulo de reservas - que passaram de US $\$ 289$ bilhões em 2010 para US\$ 363 bilhões em 2014 (BCB, 2018) - diante de um elevado diferencial de juros interno e externo foi cara e impactou a política fiscal. Não obstante, a isso ainda se somaram as operações swaps cambiais (inclusive o uso de swaps reversos) para administrar a desvalorização cambial, porém custosas, o que contribuiu com a deterioração das contas públicas, emitindo sinais negativos para os agentes ${ }^{7}$.

Em suma, as políticas de crédito, sociais e salarial, juntamente com o miniciclo das exportações (até 2011, neste caso) impulsionaram em alguma medida a economia, mas a TCR permaneceu apreciada, levando à deterioração dos lucros e das transações correntes, além de impor um teto para o investimento privado e, consequentemente, para os ganhos de produtividade. Inviabilizaram-se, assim, os objetivos da própria política social a médio/longo prazo, por eles serem insustentáveis quando comparados às condições estruturais da produção, sem ganhos de produtividade, dada a ausência de investimentos. Controle de capitais, acumulação de reservas externas e operações de swaps cambiais, embora bem-intencionados em termos de consecução de política macroeconômica, ao alinharem-se à descoordenação da forma de conduzir a política econômica como um todo, emitiram sinais contraditórios aos agentes, visto que estas medidas eram instáveis e/ou produziram piora na situação fiscal do governo. $\mathrm{O}$ resultado deste quadro retroalimentou o estímulo a convenções pessimistas sobre o futuro da economia.

\subsubsection{Política monetária}

Em seu primeiro ano, o governo Dilma apostou numa mudança na política monetária. Medidas macroprudenciais de controle do crédito foram adotadas e a taxa Selic foi reduzida de $12,5 \%$ para $7,25 \%$ entre agosto de 2011 e outubro de $2012^{8}$. No segundo semestre de 2012 a taxa de juros futura marcada a mercado para um ano à frente caía, seguindo a Selic. Ou seja, o BC conseguiu difundir no mercado financeiro a convenção de que a política monetária teria êxito, levando os agentes a precificarem juros futuros menores, afetando a curva de juros do sistema financeiro na direção indicada pelo BC. No final de 2011, parte das medidas macroprudenciais foi revertida, enquanto bancos públicos reduziram suas taxas de juros e ampliaram o crédito, forçando com êxito a redução dos spreads de todo o sistema bancário.

Porém, após um acompanhamento pari passu ao longo do segundo semestre de 2012, no início de 2013 a taxa de juros futura de mercado se descolou da Selic, sinalizando que a convenção sobre política monetária estava mudando, dado o aumento da inflação esperada, associada, em boa medida, à desvalorização cambial no período e a alguma pressão de demanda contra uma oferta que não se expandia em termos de aumento do estoque de capital pelo

(7) O Brasil tinha em 2014 um passivo de quase US\$ 100 bilhões decorrente das operações com derivativos cambiais, valor que representava quase um terço das reservas externas do país (Arestis; Terra, 2015).

(8) Sobre as medidas macroprudenciais, ver Serrano e Summa (2015, p. 19). 
investimento insuficiente e pelo pleno emprego no mercado de trabalho. Neste cenário, sendo a taxa de juros um fenômeno convencional, o BC teria que reverter uma parte da queda da Selic para mostrar seu comprometimento com o controle da inflação e, assim, tornar crível sua política monetária, aumentando um pouco os juros básicos para sustentar pelo menos parte da redução anterior dos juros, uma estratégia um passo atrás, dois passos à frente. Porém, isto não foi feito.

Ao invés de elevar a Selic, revertendo parcialmente sua queda, o governo optou por acomodar a inflação por meio de controle de preços administrados, principalmente petróleo e derivados, e mudando unilateralmente contratos de energia elétrica. Neste contexto, o BC passou a perseguir o teto da meta de inflação ao invés do seu centro. Estas medidas foram mal comunicadas aos agentes e, assim, desconsideraram-se suas expectativas sobre os objetivos da política econômica.

Não obstante, provavelmente por causa das eleições em 2014, o BC demorou para aumentar a Selic, fazendo persistir a discrepância entre os juros básicos e a taxa futura marcada a mercado, ajudando a deteriorar ainda mais a convenção sobre uma pior inflação futura. Quando o BC finalmente aumentou os juros, a convenção já era tão negativa que ele foi obrigado a realizar forte aumento da Selic e a mantê-la elevada mesmo com a economia entrando em recessão, ao longo de 2015 e 2016, criando um elevado custo de oportunidade para o investimento no momento em que o país muito necessitava dele. Os juros altos em meio à recessão eram o preço pago pelo $\mathrm{BC}$ para reconquistar as convenções dos agentes.

\subsubsection{Incoerências das políticas macroeconômicas}

Havia, portanto, equívocos, incoerências e contradições no conjunto das políticas fiscal, cambial e monetária levadas a efeito pelo governo Dilma. Ao mesmo tempo em que o BC errava na condução da política monetária, várias contradições se observavam: o PAC propunha aumento do gasto com investimento público enquanto que isenções tributárias e operações com derivativos cambiais deterioravam as contas públicas; o câmbio apreciado colocava um teto para investimentos privados, inibindo o aumento da produtividade, em um contexto de aumento real dos salários e outras medidas de estímulo ao consumo (politicas creditícia e de transferência de renda). O governo buscava estimular o investimento privado, mas tomava uma série de medidas que afetavam a confiança empresarial, como a quebra unilateral de contratos no mercado de energia e repressão de alguns preços administrados.

As contradições de cada uma dessas políticas e a falta de coordenação entre elas impediram a emergência de um requisito central para que o investimento agregado se elevasse o requerido para o crescimento sustentado da economia: a convenção dos agentes em uma política econômica estável e crível o suficiente para se esperar um futuro promissor e lucrativo. A Figura 1, a seguir, traz seis diferentes Índices de Confiança, quais sejam, da Indústria, Comércio, Serviços, Consumidor, Empresarial e da Construção. À exceção dos Índices do Consumidor e da Construção, todos os outros mostram uma tendência de queda a partir de 2012; os do Consumidor e da Construção, por sua vez, mostram esta tendência a partir do final de 2013 e início de 2014. 
Figura 1

Índices de confiança diversos

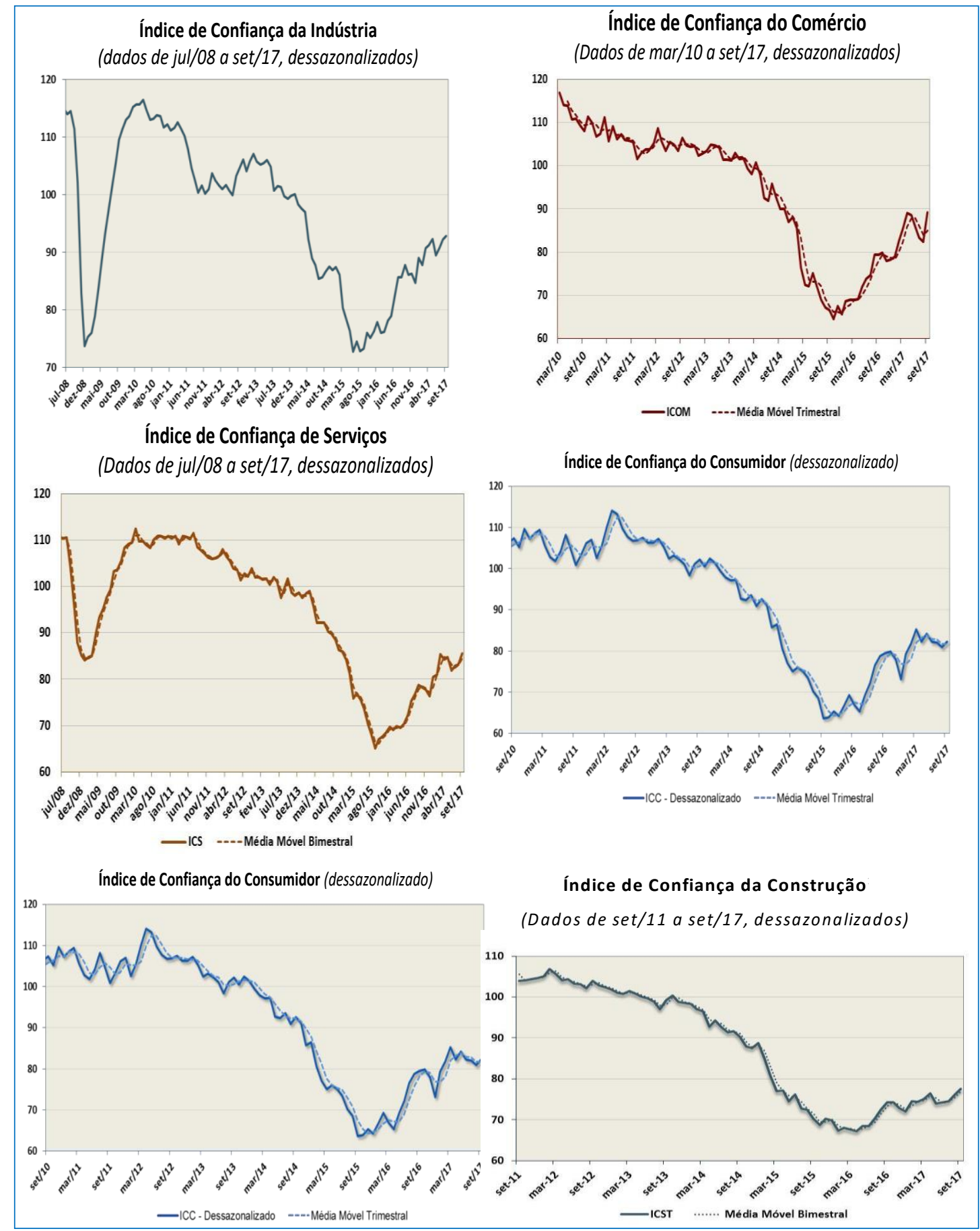

${ }^{1}$ Fonte: Instituto Brasileiro de Economia da Fundação Getúlio Vargas (2019).

Notas: ICOM - Índice de Confiança do Comércio; ICS - Índice de Confiança do Serviços; ICC - Índice de Confiança Empresarial; ICST - Índice de Confiança da Construção. Os períodos diferentes das figuras decorrem da disponibilidade de dados. 
Seus descolamentos em relação aos demais Índices vêm do baixo nível de desemprego, que vigorou até 2014, e da estável demanda por construção civil em função do programa Minha Casa Minha Vida e das obras para a realização da Copa do Mundo de 2014 e dos Jogos Olímpicos de 2016. De uma forma geral, contudo, todos os Índices têm clara tendência de queda da confiança. Importa notar que a tendência de queda se verifica antes dos choques que abalam a economia brasileira, como a operação Lava Jato, a crise hídrica, a queda dos preços internacionais das commodities, que ocorrem a partir de 2014 - o miniciclo de aumento dos preços das commodities ocorreu até 2011, mas a forte queda de seus preços deu-se em 2014. $\mathrm{Na}$ ausência de choques externos e internos relevantes, que somarão como causas da crise apenas partir de 2014, resta à errática coordenação de política econômica do período 2011 2014 ser o fator desencadeador de convenções pessimistas sobre a economia brasileira.

O resultado destas inconsistências foi a reversão da confiança em relação ao futuro, algo que, para Keynes (1973, cap. 22), é o ponto de inflexão das expectativas, responsável pela eclosão das crises. Embora alguns fatores se somem para promover o arrefecimento do crescimento econômico brasileiro a partir de 2011, a crise (entendida como a confluência dos vetores que levariam à recessão de 2015-2016) iniciou-se em 2013, quando há a inversão na trajetória dos investimentos a partir do quarto trimestre: as taxas de investimento/PIB entre o primeiro trimestre de 2013 e o último de 2014 foram, respectivamente, 20,67\%, 21,14\%, $21,52 \%, 20,34 \%, 20,73 \%, 19,85 \%, 19,81 \%$ e $19,16 \%$, e caíram continuamente até o quarto trimestre de 2016, quando atingiu 14,68\% (IBGE, 2018). Como resultado, já em 2014, a economia brasileira cresceu apenas $0,5 \%$.

Veja-se que o nível anual da taxa do investimento agregado não cai até 2014. Seu crescimento desacelera-se a partir de 2011, mas ela cresce continuamente, embora a taxas pequenas, passando de 20,5\% do PIB em 2010 para 20,9\% em 2013. Se entre 2004 e 2010 a elevada capacidade ociosa permitia que o investimento fosse preterido enquanto o componente da demanda a liderar o crescimento econômico, o mesmo não se pode dizer do período pós2010, quando o crescimento precisava, para ser sustentável e mudar para nível superior, da expansão dos investimentos. Contudo, pós-2010, havia taxas menores de crescimento do consumo e das exportações, que se somavam para não incentivar taxas crescentes de aumento do investimento. Neste particular, a desaceleração das taxas de variação do investimento foi, assim, secundária na explicação da queda no ritmo de crescimento da economia entre $2011 \mathrm{e}$ 2013, porém, para a expansão da taxa de variação do crescimento do PIB, mais investimento era necessário. Trocando em miúdos: o investimento não contribuiu para arrefecer a taxa de crescimento do PIB até 2013, porém também não ajudara a elevá-la. Neste período, a principal explicação da desaceleração da economia em termos dos componentes da demanda e, portanto, desconsiderando-se as convenções, foi a menor taxa de crescimento nos mesmos itens identificados como os motores principais do crescimento da fase anterior: exportações e, sobretudo, o consumo privado. Isso, porém, não justificaria um crescimento negativo do produto, mas apenas a entrada e permanência em uma tendência de menores expansões do PIB. 
Logo, o que se verificou de 2011 em diante foi um arrefecimento da dinâmica de crescimento de consumo e exportações em relação ao período 2004-2010, pois, (i) nas exportações, a Crise do Euro, a redução do ritmo de crescimento chinês e dos emergentes, o fim do miniciclo de commodities, a "Guerra Cambial", etc., estabilizaram os preços das exportações brasileiras e, dado o antes mencionado câmbio real valorizado em concomitância com aumento real de renda, as importações se expandiram, reduzindo o push das exportações líquidas para o PIB; e (ii) no consumo, o endividamento das famílias se elevou e, após o choque de juros e a concorrência forçosa no sistema bancário, por meio do uso dos bancos públicos para praticarem menores juros de varejo no mercado de crédito e no financiamento imobiliário, os bancos privados restringiram crédito - tanto que, entre 2013-2014, antes da crise portanto, os bancos privados reduzem sua participação relativa no total de ativos detidos pelo sistema bancário no Brasil (Brasil, 2019). Assim, em âmbito geral, o consumo via crédito perdeu ritmo, comprometendo as taxas de expansão do consumo agregado. Portanto, a desaceleração da taxa de crescimento econômico a partir de 2011, o que não quer dizer recessão, veio do arrefecimento do crescimento das exportações e do consumo privado. Isto é, a demanda agregada cresceu a uma velocidade menor e implicou menor ritmo de aumento do produto, mas ainda se tinha crescimento. Para reverter esta tendência e mudá-la, estimulando-se uma taxa de expansão da demanda que puxasse o produto a um nível de crescimento maior, de acordo com as prescrições de política econômica de Keynes, era necessária uma política econômica contracíclica que, se capaz de construir convenções positivas e gerar expectativas otimistas, estabilizaria automaticamente o ciclo. Porém, o que se viu foi uma política macroeconômica errática, inconsistente entre si e descoordenada em suas ações que, conforme se nota na Figura 1, incentivou a ida de uma convenção otimista para uma outra pessimista no percurso entre 2011 e 2013. Deste modo, impediu-se que a taxa de investimento crescesse para estabilizar e estimular o crescimento do produto, compensando as taxas decrescentes de expansão do consumo privado doméstico e das exportações líquidas.

\section{O Brasil em recessão: políticas fiscal, cambial e monetária após 2014}

Após a reeleição de Dilma Rousseff em 2014, o Ministério da Fazenda propôs uma meta de superávit primário de 1,2\% do PIB para 2015, optando por uma mudança radical na política econômica, com consolidação fiscal baseada principalmente em corte dos gastos públicos e, logo em maio de 2015, o governo anunciou um contingenciamento de cerca de $\mathrm{R} \$$ 80 bilhões. Paralelamente, ocorriam o derretimento dos preços internacionais das commodities, a crise hídrica do período 2013-2015, e, principalmente, a operação Lava-Jato, que atingiu os investimentos da Petrobrás e das grandes empreiteiras do país. A taxa de investimento, cujo pico fora 20,9\% do PIB em 2013, caiu para 17,8\% em 2015 (IBGE, 2018), enquanto que o crescimento econômico foi de $-3,5 \%$ naquele ano e $-3,3 \%$ em 2016. A recessão contribuiu, provavelmente de modo decisivo, para o impeachment da presidente em agosto de 2016 . Neste particular, note-se que neste período os Índices de Confiança se elevaram, ainda que em pequena monta, mas talvez refletindo a esperança de inflexão na trajetória da economia, como reportou a Figura 1. 
A dinâmica da economia brasileira entre 2011 e 2014 teve duas características marcantes, a saber, uma queda da sua taxa média de crescimento em relação ao período anterior, 2006-10, e uma quebra estrutural na série da sua taxa de crescimento entre 2013 e 2014, como mostra o Gráfico 2. O crescimento da economia nos anos do primeiro governo Dilma caiu de patamar em relação ao período do segundo governo Lula: a taxa média anual naquele governo foi 2,35\%, e, neste, 4,65\%. Em 2011, o crescimento econômico de $4 \%$ foi afetado pelo carregamento estatístico do crescimento de 2010, que foi de 7,5\%. Em 2012 e 2013 o PIB real cresceu 1,9\% e 3\%, respectivamente. Esta queda de patamar, antes dos choques mencionados acima, pode ser explicada pelas inconsistências da política econômica apontadas anteriormente, além da piora no cenário externo e do arrefecimento do aumento do crédito ao consumo nos primeiros anos do governo Dilma. Todavia, após alcançar 3\% em 2013, a taxa de crescimento econômico caiu para 0,5\% em 2014 e tornou-se negativa em 2015 mostrando uma tendência de queda contínua entre 2014 e 2015. Logo, percebe-se uma quebra estrutural na série da taxa de crescimento da economia entre 2013 e 2014, final do primeiro Governo Dilma.

Gráfico 2

Taxa de crescimento real da economia brasileira, 2004-2016 (em \%)

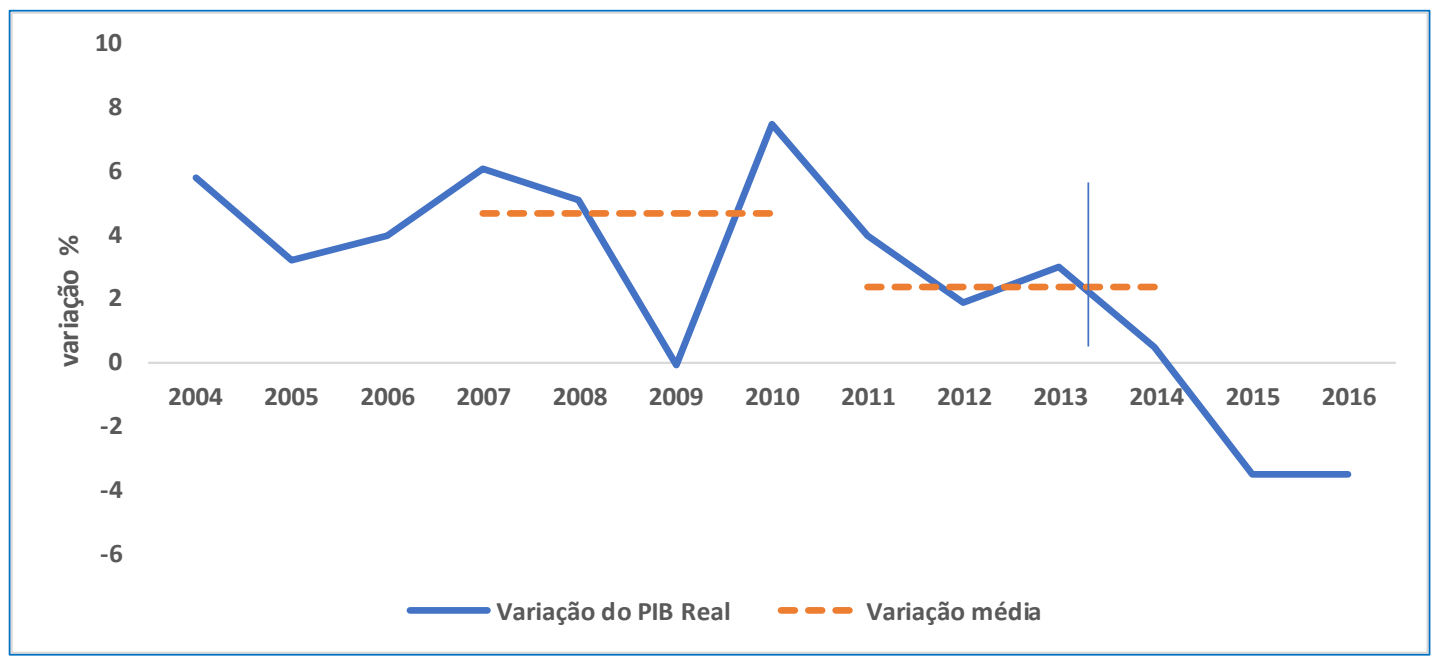

Fonte: BCB (2018).

É importante mencionar o relevante impacto da Lava-Jato ${ }^{9}$ em 2014 para formar a crise, pois a operação veio em um ambiente de expectativas já deterioradas por políticas econômicas inconsistentes, crise e cisão políticas em ano eleitoral, crise hídrica e queda dos preços das commodities. Iniciada em 2009, mas cuja primeira fase ostensiva sobre as

(9) O argumento de que o colapso da economia em 2015-16 resultou da "defasagem externa" de política econômica equivocada, aplicada em 2011-14, é frágil, visto que, se assim fosse, a recessão não teria chegado abruptamente. Isto é, não haveria quebra estrutural na série da taxa de crescimento da economia entre 2013 e 2014, mas apenas deterioração contínua do desempenho da economia após estes dois anos, em correspondência temporal à implementação paulatina das políticas equivocadas entre 2011 e 2014. 
organizações criminosas fora deflagrada em março de 2014, a Lava-Jato afetou diretamente a Petrobrás - responsável, sozinha, por 8,9\% do investimento agregado no Brasil em 2013 (Loural, 2016) - e grandes empreiteiras responsáveis por investimentos em infraestrutura ${ }^{10}$. Com efeito, os Índices de Confiança apresentados na Figura 1 mostram queda entre meados de 2011 e finais de 2012 em diante, com pequena melhora somente após meados finais de 2016, época de consumação do Impeachment de Dilma Rousseff.

Em 2015 o governo tentou implementar um programa de consolidação fiscal baseado em corte de gastos, ao invés de reorganizar suas contas aumentando impostos sobre renda de pessoa física e propriedade e substituindo gastos correntes por investimento. No âmbito de desaceleração/recessão econômica, mesmo um necessário ajuste fiscal tende a não ter êxito quando feito através do corte de gastos: nesta conjuntura deteriorada, menores gastos públicos desestimulam a atividade econômica e mitigam a própria arrecadação do governo, enquanto que agentes privados optarão por ativos líquidos, postergando investimentos. Ou seja, o ajuste fiscal poderia contribuir para a construção de convenções mais críveis na política econômica, mas, dada a natureza do ajuste proposto, dificilmente ele ajudaria a se erigirem convenções pró-investimento, pois, por si, ele significava expectativas de menor demanda agregada. $\mathrm{O}$ investimento agregado desabou, com queda real de 13,9\% em 2015 e 10,3\% em 2016 (BCB, 2018). Não à toa, os Índices de Confiança desabaram entre janeiro e outubro de 2015 , alcançando seus menores níveis, como apresentado na Figura 1.

Em meio à recessão, que traz receitas públicas cadentes, e à rigidez dos gastos públicos, tanto 2015 quanto 2016 foram anos de déficit público, isto é, a consolidação fiscal falhou. Inclusive, conforme SPE (2018), a política fiscal foi expansionista em 2016 e mesmo assim o PIB decresceu 3,3\%. O empresário continuou em sua tendência vinda pelo menos desde 2014: convencionando que melhor é esperar alocado em liquidez do que em ativos ilíquidos de capital $^{11}$.

Na perspectiva Pós-Keynesiana, o desequilíbrio fiscal contínuo estimula convenção pessimista sobre o futuro e deve ser combatido. Porém, o ajuste fiscal precisa ser feito balanceando-se gastos correntes e de capital, isto é, aumentando-se o segundo, que tem forte

(10) Paula e Moura (2019) mostram em números o impacto drástico da Lava-Jato nas cadeias de petróleo e gás e construção civil, bem como o severo desmonte e descapitalização das maiores empreiteiras do país.

(11) Começou a partir de meados de 2014 a discutirem-se os problemas decorrentes da deterioração da situação fiscal e do crescimento acelerado da dívida pública, o que desencadeou uma série de convenções sobre, por um lado, as causas de tal crescimento e, por outro lado, se ele levaria o Brasil à bancarrota. As discussões sobre a questão fiscal dominaram, por sinal, a campanha eleitoral de 2014 e que, após a indicação de que seria necessária uma política de austeridade fiscal pela candidata reeleita em 2014, Dilma Rousseff, após ela ter afirmado durante a campanha que a situação das finanças públicas não era problemática, ganharam peso convencional bastante generalizado. Como toda discussão sobre construção de convenções, as narrativas que se colocam vêm de disputas de poder das mais variadas fontes e, neste sentido, agentes interessados em resguardar seus interesses especulativos na dívida pública, como o sistema financeiro, sobretudo os bancos e os fundos de investimentos, contribuem para reforçar a narrativa de insustentabilidade do crescimento da dívida em relação ao PIB. A depender de como estas narrativas ganham setores importantes de divulgação de informações, como a mídia e as redes sociais, a convenção torna-se bastante disseminada e seu poder de crença intensifica-se, ainda que com elementos questionáveis em termos objetivos. 
efeito multiplicador, mesmo que às custas da redução do primeiro. Ademais, no contexto de recessão econômica, havendo espaço político, parte do ajuste deve recair sobre aumento de impostos sobre renda e propriedade de pessoa física, e com cunho progressivo. Apenas com uma régua única, de corte horizontal da totalidade dos gastos públicos, os agentes não têm estímulo a reduzir sua preferência pela liquidez, levando à queda da demanda e da produção agregadas, à redução da arrecadação do governo e, muitas vezes, ao resultado oposto daquele buscado: o aumento do desequilíbrio fiscal, da dívida pública e deterioração das expectativas. Foi exatamente isso o que se viu na economia brasileira no final de 2015, com o governo apresentando um déficit primário de 1,88\% do PIB. No biênio 2015-16 a queda do PIB foi cerca de $7 \%$ e, logo, o desemprego alcançou 13,7\% no primeiro trimestre de 2017.

Porém, no desespero por recuperar a credibilidade em suas políticas econômicas, mas sem se preocupar em efetivamente reformar o orçamento público para o construir com potencial contracíclico, via orçamentos corrente e de capital, o governo que se seguiu ao impeachment de Dilma Rousseff continuou com a busca pela austeridade fiscal, porém desta vez implementada na forma de uma Emenda Constitucional (95/2016), a chamada Regra do Teto de Gastos que, diga-se de passagem, havia aparecido de forma incipiente na proposta do governo de Michel Temer, intitulada 'Ponte para o Futuro'.

Em dezembro de 2016 fez-se promulgada a referida Emenda Constitucional 95, que limitou por 20 anos a variação da despesa primária do governo federal à inflação acumulada no Índice de Preços ao Consumidor Amplo (IPCA), visando à queda da participação real dos gastos públicos no PIB à medida que este crescesse em termos reais ${ }^{12}$. Despesas financeiras, como o pagamento de juros ou o montante de amortizações, não entram na regra e, portanto, o limite de variação se aplica apenas aos dispêndios primários. Visto que gastos obrigatórios, como previdência, crescem vegetativamente, o discricionário investimento público, já minguado, tem sido o item sacrificado para o cumprimento do Teto. Por demais influenciada pelo ciclo econômico, e por de menos atento a ele, a regra de limite de gastos pode ser inexequível bem antes de seu fim (parcial) previsto para 2026. Daí a corrida pela reforma da previdência.

Na visão Pós-Keynesiana, o Teto dos Gastos é um equívoco. Um plano de investimentos públicos é crucial para coordenar expectativas e estimular o investimento privado, e sua importância enquanto componente contracíclico de demanda é reforçada em períodos recessivos. Por fim, o Teto não se sustenta no curto/médio prazo, além de comprometer gastos de investimento em áreas vitais para o crescimento da produtividade e da economia a longo prazo, como saúde, educação e infraestrutura.

Por sua vez, o déficit nominal do governo foi recorde em 2015, 10,22\% do PIB, devido em grande medida à queda da sua arrecadação ter sido maior do que sua redução de gastos e à forte elevação do pagamento de juros, em função da convenção negativa acerca das finanças

(12) Despesas primárias com transferências constitucionais, créditos extraordinários, gastos com eleições e despesas com aumento de capital das estatais não dependentes não entram na regra do Teto. 
públicas no médio prazo e também do aumento da Selic pelo BC. A aguda deterioração das expectativas também contribuiu, entre outros motivos, para a maxidesvalorização cambial de 48\% em 2015 (BCB, 2018), que também ajudou no choque altista na taxa Selic. Além disso, também em 2015 o governo realinhou abruptamente tarifas de eletricidade e combustível. Embutindo ambos os fatores, a inflação foi a 10,67\% naquele ano. O aumento de juros e a recessão resultaram em forte endividamento e crise de solvência do setor privado (famílias e empresas) e contração do crédito. Neste quadro, o colapso da economia foi esticado para 2016.

A taxa de juros Selic alcançou 14,25\% em agosto de 2015 e o BC só flexibilizou a política monetária a partir de outubro de 2016. Em passo lento frente à dimensão da crise pela qual passava o país, apenas em março de 2018 a Selic alcançou seu menor patamar até então, 6,5\% ao ano (em setembro de 2019 a Selic, pela persistência da crise, alcançou 5,5\%, o menor nível de sua história). O IPCA saiu de 10,67\% em 2015, para 6,29\% em 2016 e 2,95\% em 2017 (IBGE, 2018). A desvalorização cambial de cerca de $50 \%$ verificada entre janeiro e setembro de 2015, concomitantemente ao realinhamento abrupto de tarifas públicas, produziu grande impacto inflacionário que, por sua vez, requereu tempo para se dissipar. Conforme Maciel (2006), cerca de 50\% do repasse cambial à inflação no Brasil ocorre em período superior a 10 meses. Logo, a dissipação do efeito inflacionário do choque de câmbio e de tarifas só terminaria de meados de 2016 em diante.

Então, o que parece ter ancorado as expectativas e controlado a inflação em 2016 foi a recessão do biênio 2015-16. Se esta tese procede, então o longo tempo de permanência da Selic em $14,25 \%$ ao ano foi um erro de política monetária, pois os juros ficaram mais tempo elevados do que o necessário, o que contribuiu para deteriorar as contas públicas e as expectativas dos agentes sobre a política fiscal, além de aprofundar e prolongar a recessão e o desemprego. Com efeito, o IPCA em 2017 ficou na banda inferior da meta, sugerindo o conservadorismo do BC. O único alento observado no período foi a melhora das contas externas: o déficit em conta corrente caiu de 4,24\% do PIB em 2014 para 1,31\% do PIB em 2016 (BCB, 2018).

\section{Alternativas de políticas macroeconômicas para a crise}

Um conjunto de fatores explica o crescimento econômico brasileiro de $1 \%$ em 2017 e 2018, além do próprio caráter cíclico da recuperação. A economia mundial ganhou força após 2015, impulsionando as exportações brasileiras. No plano interno, em 2017, a liberação de recursos do FGTS estimulou diretamente a demanda e favoreceu o resgate de dívidas no sistema bancário e o acesso ao crédito. Houve safra agrícola recorde e aumento dos preços internacionais das commodities, além de continuada queda da taxa de juros Selic e da inflação, estimulando a demanda agregada.

Não obstante, a retomada ainda se sustenta em bases frágeis. A capacidade ociosa na economia e a taxa de endividamento de famílias e empresas ainda são elevadas. Logo, a taxa de crescimento do crédito para níveis pré-crise será lenta, seja porque o investimento privado fica postergado enquanto houver elevada capacidade ociosa, seja devido à cautela do sistema 
financeiro na oferta de crédito. De outro lado, a dívida do setor público continua alta e crescente e o resultado primário permanece deficitário, sendo o corte de investimentos públicos o recurso do governo para cumprir a meta de primário, a Regra de Ouro e o Teto dos Gastos. Ademais, a Taxa de Longo Prazo (TLP), que substituiu em janeiro de 2018 a Taxa de Juros de Longo Prazo (TJLP), está atrelada ao título do Tesouro, NTN-B, e ao longo dos próximos cinco anos se aproximará da taxa de juros de mercado, tornando-se mais volátil e encarecendo investimentos financiados pelo BNDES. Some-se a isto uma tímida retomada do emprego, porém, precarizado na esteira da reforma trabalhista, com ênfase no mercado informal. Portanto, este quadro não sugere expectativas alvissareiras, pois não se aponta convenção otimista de que haverá investimento privado e uma retomada forte e sustentada do crescimento econômico brasileiro.

$\mathrm{Na}$ perspectiva Pós-Keynesiana, o crescimento sustentado da economia requer coerência e coordenação entre as políticas econômicas. Elas são parte responsável por convenções sobre um futuro melhor e, então, cruciais para estimular o investimento privado. Porém, convenções positivas só emergem se os agentes acreditam que a política econômica é coerente, factível e adequada. São necessárias, entre outras medidas, as políticas macroeconômicas delineadas a seguir.

Em termos da política fiscal, o desequilíbrio fiscal e descontrole da dívida pública deterioram as expectativas dos agentes, levando à retração dos investimentos. A retomada do crescimento econômico pode ser feita utilizando-se a capacidade ociosa, porém, sua sustentação depende de única variável: o investimento. Logo, o desequilíbrio fiscal brasileiro tem que ser corrigido. A política fiscal deve ser contracíclica, baseada em plano de investimentos públicos com orçamento de capital factível. A convenção na viabilidade do plano de investimentos e no seu caráter contracíclico estimula os agentes a alocar sua riqueza em ativos de capital fixo mesmo diante de um futuro incerto. Este é o caráter de coordenação de expectativas privadas do plano, emitindo sinais para guiar as decisões de gasto dos agentes que impulsionarão o crescimento econômico. Para ser crível e garantir expectativas de que o plano de investimentos públicos contribuirá para sustentar a demanda agregada futura, o orçamento de capital deve ser transparente e mostrar coerência entre os gastos planejados e a fonte dos recursos - impostos vinculados ao financiamento do investimento público confere coerência a este quesito.

O colapso das contas públicas e o ambiente de muita incerteza no Brasil requerem um ajuste fiscal que permita o aumento do investimento público. Dado o frágil nível da atividade econômica, tal ajuste deve ser feito por meio de aumento de impostos sobre renda e propriedade de pessoa física, com cunho progressivo. O setor público deve implementar suplementação de gastos, contingenciando gastos correntes e transformando-os em gastos de capital, a bem de elevar o nível de investimento público e aumentando a viabilidade de ele ser multiplicador de renda, algo bastante diverso do que tem sido feito nos últimos anos. 
O Teto dos Gastos é uma política contrária à prescrição de política fiscal Keynesiana. Ele deve ser eliminado pelo Congresso e o aumento dos gastos de investimento público deve estar calcado na redução de gastos correntes do governo, no aumento de impostos e coerente com a perspectiva de recuperação da arrecadação pública futura com a retomada do crescimento econômico. Mesmo com essa recuperação em médio prazo, deve ser feita reforma tributária progressiva, com redução da carga de impostos indiretos e aumento de impostos diretos: taxação de lucros e dividendos da pessoa física (atualmente inexistente), inclusão de nova alíquota do imposto de renda de pessoa física, coibir a "pjotização", taxar herança e propriedade de meios de transporte de luxo, como iate, jato particular e helicóptero, algo hoje inexistente, regulamentação do imposto sobre grandes fortunas, etc. Imposto sobre exportação de commodities também deve ser implementado para combater a "doença holandesa", que leva à apreciação cambial e que, portanto, é nociva ao investimento. A redução de impostos indiretos deve recair sobre bens salários (alimentos básicos, bens de consumo leve, remédios, etc.).

O aumento da arrecadação com reforma tributária e imposto sobre exportação de commodities alimentaria um fundo de investimento público em infraestrutura (incluindo petróleo, energia em geral e construção civil), de cunho contracíclico, visando coordenar expectativas sobre o nível mínimo da demanda agregada futura e redução de custos de produção, com efeito sobre produtividade e lucros esperados. Seria uma espécie de PAC contracíclico, com o governo investindo, inclusive com a participação do capital privado, em setores estruturantes em que o setor privado em geral não investe sozinho, e que realmente tenha coerência, credibilidade e induza convenções otimistas e o crowding-in dos investimentos privados. Ainda deve ser feita a revisão dos regimes de desoneração e subsídios que prevalecem atualmente, e, por fim, a reforma da previdência se faz necessária, dadas as tendências demográficas.

Pelo lado dos gastos, aqueles de cunho social e que melhoram a distribuição da renda devem ser adotados. A distribuição da renda é uma questão de justiça social e é uma reforma institucional que afeta a estrutura e a harmonia social, aumentando a eficiência dos canais de coordenação entre os agentes e orientando seu comportamento futuro. Ela aumenta a propensão a consumir da sociedade, estimulando sua confiança no futuro, o animal spirits e o investimento.

Até onde podem ir aumentos de impostos e de gastos públicos sociais e de investimento? Estas medidas seriam calibradas dentro do possível e tendo como referência o controle da relação dívida/PIB, ancorando as expectativas. Ou seja, o orçamento de capital deve ser intertemporalmente equilibrado, permitindo o controle da relação dívida pública/PIB e, logo, convenções positivas. Tais medidas melhoram a distribuição da renda e desoneram o produtor doméstico, aumentam a produtividade e competitividade da economia, abrindo espaço para convenção otimista e confiança no futuro, estimulando o investimento e seu crescimento sustentado. 
Para a política cambial, uma TCR apreciada inibe o investimento e leva à desindustrialização e à reprimarização da estrutura produtiva e da pauta de exportações, prejudicando os ganhos de produtividade e o crescimento econômico de longo prazo. Este quadro ocorre no Brasil desde o final do século XX, interrompido por momentâneas e fortes depreciações cambiais. Na abordagem Pós-Keynesiana, o câmbio não é uma variável passiva. Visto que é o investimento que causa renda e poupança, não é a escassez desta que provoca aumento dos juros, atração de capitais externos e consequente apreciação cambial, levando ao aumento da poupança externa captada por déficit em transações correntes. Poupança é resíduo, estando sempre ao final do processo. Ela é pequena porque o investimento é baixo e este é baixo não porque a poupança é baixa, mas, sim, porque o é o finance (Arestis; Resende, 2015). A TCR, por sua vez, determina a parcela do estímulo do investimento doméstico para a formação de poupança que vazará para o exterior, aos parceiros comerciais do país. O investimento causa a poupança, mas parcela dela pode ser formada no exterior, via déficit em transações correntes, em uma economia aberta. Quanto mais apreciada for a TCR, maior será o vazamento da poupança para o exterior (Arestis; Resende, 2015).

Taxa de juros elevada atrai capitais externos, apreciando o câmbio. Portanto, a autonomia de política monetária e a administração adequada da taxa de câmbio requerem controle de capitais (Keynes, 1980b). Os controles viabilizam um regime de câmbio administrado, o que oferta uma taxa mais estável, sendo a estabilidade cambial crucial para dar previsibilidade aos agentes, imprescindível para construir confiança em convenção otimista e estimular o investimento privado.

Os gaps de produto e emprego, dada a Regra de Taylor para determinação da taxa de juros no Brasil, além de expectativas baixistas sobre a inflação esperada, permitem baixar ainda mais a taxa Selic, já em piso histórico, favorecendo a depreciação cambial. O cenário de fraca atividade produtiva, alto desemprego, elevada capacidade ociosa, baixa inflação e juros internacionais facilitaria o processo e arrefeceria os efeitos inflacionários de maior depreciação cambial, que seria controlada também pelos controles de capitais. Porém, mudanças no cenário mundial, atualmente com taxas de juros muito baixas, podem levar a correções na estratégia de política cambial. A política de depreciação administrada da taxa de câmbio contaria também com o imposto sobre exportação de commodities, anulando a doença holandesa.

O efeito inflacionário da desvalorização cambial sobre a população mais pobre, se ocorrer, pode ser parcialmente compensado com políticas sociais: cite-se o aumento do valor da bolsa família, redução de impostos sobre bens salários, preservação do valor real do salário mínimo, aposentadorias e pensões. Os ganhos reais de salários, contudo, não podem ficar acima dos ganhos de produtividade da economia, sob pena de atingirem a taxa de lucro e o investimento. 
Por fim, na política monetária, a taxa Selic ainda está elevada (sobretudo se comparada ao padrão internacional atual), prejudicando as contas públicas ${ }^{13}$. A redução da taxa de juros é imprescindível, porém sem voluntarismo e sem se descuidar do controle da inflação. A rubrica juros é, há tempos, um dos três principais gastos do governo e juros altos implicam menores recursos para políticas contracíclicas e sociais, inibindo convenções otimistas.

Sua redução, contudo, deve ser facilitada a partir das seguintes premissas: (i) o regime de metas de inflação deve ser flexibilizado com a ampliação do horizonte de convergência da inflação à meta (somente Israel e Brasil adotam o prazo de um ano) e isso deve ser bem comunicado com a sociedade; (ii) deve-se promover a desindexação dos preços administrados, como energia elétrica, planos de saúde, remédios, transporte público, telefonia, etc., que formam cerca de 30\% do IPCA; (iii) redução da regressividade tributária; e, (iv) a resolução da "jabuticaba" brasileira: o grande volume de aplicações financeiras no mercado de títulos públicos remuneradas à taxa Selic, que retira eficiência da política monetária por eliminar o efeito-riqueza, sendo uma das razões para a taxa de juros ser elevada no Brasil. Ademais, títulos públicos indexados à Selic levam o $\mathrm{BC}$ a ter que remunerar as operações de política monetária no mercado de reservas bancárias segundo a própria taxa do interbancário, Selic, tornando os títulos públicos e reservas bancárias substitutos perfeitos e surgindo uma contaminação da política monetária pela dívida pública, fazendo com que a taxa interbancária incorpore o prêmio de risco da dívida pública. Dado o perfil de curto prazo desta, quando o governo tenta baixar a taxa de juros que remunera os títulos públicos no processo de rolagem da dívida, o mercado financeiro tem a opção de levar seus recursos para o mercado de reservas bancárias (interbancário). Este jogo permitido pelo mercado de dívida pública brasileiro gera uma pressão altista na taxa de juros (Paula; Bruno, 2017).

O objetivo da política monetária é afetar a curva de rendimentos do sistema financeiro para estimular o investimento privado, porém tal curva depende da resposta dos agentes à política monetária. Logo, se a convenção sobre esta é crível, a curva de juros é afetada na direção apontada pelo BC. Se a intenção do BC é reduzir os juros, ele precisa fazer o mercado convencionar que tal redução é factível e que a política monetária terá êxito. Para que se crie uma convenção de que a queda da taxa de juros prevalecerá no futuro, o BC não pode se descuidar da inflação e nem pode conduzir uma política monetária errática e oscilante, mesmo na ausência de inflação; caso contrário tal convenção não se sustenta. Finalmente, sugere-se um duplo mandato para o BC: metas para inflação e emprego.

\section{Conclusões}

O crescimento econômico sustentado depende do investimento que, todavia, é o componente mais volátil da demanda agregada. A incerteza fundamental sobre o retorno do investimento induz a comportamentos como a preferência pela liquidez e formar expectativas

(13) Descontada a inflação dos juros nominais, o pagamento de juros reais subiu de 2,6\% do PIB em 2016, para 2,8\% do PIB em 2017. 
com base em convenções. Consequentemente, a sustentação do investimento e do crescimento econômico depende de convenções otimistas para ancorar as expectativas dos agentes, pois aquelas ensejam confiança nestas. Expectativas e convenções, contudo, não eliminam a incerteza, estando sujeitas a repentinas e bruscas alterações, pois não decorrem do cálculo probabilístico, afetando diretamente o investimento. Portanto, a convenção é um instrumento de coordenação de expectativas e cabe ao governo, em muito, moldá-la. Seu papel é convencer os agentes que suas políticas são adequadas para estimular o lucro e, portanto, o investimento privado e o crescimento econômico, criando expectativas de um ambiente econômico seguro e estável.

Ao longo do ciclo econômico brasileiro de 2004-16, contradições, incoerências e falta de coordenação marcaram as políticas fiscal, cambial e monetária, inviabilizando convenções otimistas sobre a trajetória futura da economia. Consequentemente, criou-se um teto para a taxa de investimento. Contradições, incoerências e problemas de coordenação das políticas econômicas não impediram, todavia, a fase ascendente do ciclo entre 2004 e 2010. Nela, estímulos vindos do exterior e a capacidade ociosa da economia eram elevados, a TCR só se apreciou ao longo do período, e havia espaço para o aumento da relação crédito/PIB, dos salários reais e para políticas de transferência de renda. Porém, após 2011, a mudança destes condicionantes concomitante à exacerbação das contradições e descoordenação das políticas macroeconômicas levaram à fase descendente do ciclo e, em seu último biênio, a Lava-Jato, a crise política e a equivocada política econômica produziram o colapso da economia brasileira. A retomada tímida do seu crescimento a partir de 2017 está facilitada pelo excesso de capacidade produtiva ociosa, desemprego alto e cenário externo favorável. Porém, para que o crescimento se torne sustentado, o investimento deve ser elevado e permanecer acima de $24 \%$ do PIB, o que o excesso de capacidade ociosa dificultará, pois ele precisará ser ocupado antes que novos investimentos ocorram.

As prescrições de políticas fiscal, monetária e cambial na perspectiva Pós-Keynesiana, requeridas para trazer convenções otimistas e estimular o investimento, foram analisadas para o Brasil. Porém, várias outras políticas macro e microeconômicas também são necessárias e não foram aqui tratadas: políticas comercial, financeira, de ciência e tecnologia, industrial, etc. Também fugiu à análise um limitador constante da implementação de tais políticas: os interesses que compõem os diversos grupos e classes da sociedade são antagônicos e não servem ao bem-estar social, mas, sim, aos grupos e classes dos quais se originam. Economia e política estão imbricados impedindo a liberdade do policy maker bem-intencionado para implementar políticas consistentes entre si e requeridas para o crescimento econômico sustentado. Trata-se de economia política, e o bom governo é aquele que faz convergir os diversos interesses e faz políticas econômicas com coerência e coordenação nos limites do possível. 
Marco Flávio da Cunha Resende, Fábio Henrique Bittes Terra

\section{Bibliografia}

ARESTIS, P.; RESENDE, M. F. C. Fiscal policy and the substitution between national and foreign savings. Journal of Post Keynesian Economics, v. 37, n. 3, p. 436-458, 2015.

ARESTIS, P.; TERRA, F. H. B. Economic policies to improve the current state of the Brazilian economy. Challenge, v. 58, n. 6, p. 532-549, 2015.

ASCHAUER, D. A. Is public expenditure productive? Journal of Monetary Economics, v. 23, p. 177-200, 1989.

BANCO CENTRAL DO BRASIL (BCB). Indicadores de conjuntura do Banco Central do Brasil. Brasília: BCB, 2018. Disponível em: http://www.bcb.gov.br/pec/Indeco/Port/indeco.asp.

BRASIL, G. C. Aspects of the political economy of the Brazilian banking sector: has it blocked foreign competition? Dissertação (Mestrado)-Universidade Estadual de Campinas, Instituto de Relações Internacionais, Campinas, 2019.

BRESSER-PEREIRA, L. C.; OREIRO, J. L.; MARCONI, N. Developmental macroeconomics. London: Routledge, 2015.

CALDERÓN, C.; SERVÉN, L. The effects of infrastructure development on growth and income distribution. Santiago, Chile: Central Bank of Chile, 2004. (Working Paper, n. 270).

CARVALHO, F. J. C. Expectativas, incerteza e convenções. BNDES-Biblioteca Digital, 2014.

CARVALHO, F. J. C. Keynes on expectations, uncertainty and defensive behavior. Brazilian Keynesian Review, v. 1, n. 1, 2015.

CARVALHO, L. Valsa brasileira: do boom ao caos econômico. São Paulo: Todavia, 2018.

DAVIS, J. J. M. Keynes on history and convention. In: HARCOURT, G.; RIACH, P. (Ed.). A 'second edition' of the General Theory. London: Routledge, 2005. v. 2, p. 149-162.

DEQUECH, D. On some arguments for the rationality of conventional behaviour under uncertainty: concepts, applicability, criticisms. In: SARDONI, C.; KRIESLER, P. (Ed.). Keynes, post-Keynesianism and political economy. London: Routledge, 1999. p. 176-196.

DOW, S. C. Keynes on knowledge, expectations and rationality. Conference on microfoundations for modern macroeconomics. Center on Capitalism and Society, New York, 2010 .

FERRARI-FILHO, F. Política comercial, taxa de câmbio e moeda internacional: uma análise a partir de Keynes. Porto Alegre: UFRGS, 2006.

FERRARI-FILHO, F.; CONCEIÇÃO, O. A. C. The concept of uncertainty in post Keynesian theory and in institutional economics. Journal of Economic Issues, v. 39, n. 3, p. 579-594, 2005 . 
FRITZ, B.; PAULA, L. F.; PRATES, D. M. Hierarquia de moedas e redução da autonomia de política econômica em economias periféricas emergentes: uma análise Keynesiano-estruturalista. In: FERRARI-FILHO, F.; TERRA, F. H. B. (Ed.). Keynes: ensaios sobre os 80 anos da Teoria Geral. Porto Alegre: Tomo, 2016. p. 177-202.

GALA, P. Real exchange rate levels and economic development: theoretical analysis and empirical evidence. Cambridge Journal of Economics, Cambridge, 32, p. 273-288, 2008.

INSTITUTO BRASILEIRO DE ECONOMIA DA FUNDAÇÃO GETÚLIO VARGAS. Portal Dados. 2018. Disponível em: https://portalibre.fgv.br/servicos-ibre/banco-de-dadosonline/fgv-dados/. Acesso: 17 out. 2019.

INSTITUTO BRASILEIRO DE GEOGRAFIA E ESTATÍSTICA - IBGE. Séries Históricas e Estatísticas. Brasília: IBGE, 2018. Disponível em: http://seriesestatisticas.ibge.gov.br/lista tema.aspx ?op=0\&de=75\&no=12. Acesso: 17 out. 2019.

IPEADATA. Dados Macroeconomia. Brasília: Ipea, 2017. Disponível em: http//:www.ipeadata.gov.br. Acesso: 17 out. 2019.

KEYNES, J. M. The General Theory of Employment, Interest and Money. In: THE COLLECTED Writings of John Maynard Keynes. London: Royal Economic Society/Macmillan, 1973. v. VII.

KEYNES, J. M. Activities 1940-1944: shaping the post-war world. The Clearing Union. In: THE COLLECTED Writings of John Maynard Keynes. London: Royal Economic Society/ Macmillan, 1980a. v. XXV.

KEYNES, J. M. Activities 1940-1946: shaping the post-war world employment. In: THE COLLECTED Writings of John Maynard Keynes. London: Royal Economic Society/ Macmillan, 1980b. v. XXVII.

LOURAL, M. S. Investimentos industriais no Brasil: uma análise do período 1999-2013. Tese (Doutorado)-Universidade Estadual de Campinas, Instituto de Economia, Campinas, São Paulo, 2016. 173p.

MACIEL, L. F. P. Pass-through cambial: uma estimação para o caso brasileiro. Dissertação (Mestrado em Economia)-FGV - Fundação Getúlio Vargas, Rio de Janeiro, 2006. 44p.

MINSKY, H. Stabilizing and unstable economy. Twentieth Century Fund Report, 1986.

MODENESI. A. M.; MODENESI, R. L.; MARTINS, N. M. Convention, interest rates and monetary policy: a post-Keynesian-French-conventions-school approach. In: ENCONTRO INTERNACIONAL DA ASSOCIAÇÃO KEYNESIANA BRASILEIRA, AKB, 7, Rio de Janeiro. Anais... 
Marco Flávio da Cunha Resende, Fábio Henrique Bittes Terra

OREIRO, J. L. C. Por que a taxa de investimento no Brasil é tão baixa? 2013. Disponível em: https://jlcoreiro.wordpress.com/2013/01/13/por-que-a-taxa-de-investimento-no-brasil-e-taobaixa. Acesso: 18 ago. 2019.

PAULA, L. F.; BRUNO, M. Financeirização, colaizão de interesses e taxa de juros no Brasil. Princípios, v. 151, p. 66-71, nov./dez. 2017.

PAULA, L. F.; MOURA, R. Consequências econômicas da operação Lava-Jato. Valor Econômico, 28 ago. 2019. São Paulo: Globo, 2019.

PRATES, D. M.; CAGNIN, R. F.; FREITAS, M. C. P.; NOVAIS, L. F. Balanço do regime de política macroeconômica no primeiro biênio do governo Dilma. In: BIASOTO JUNIOR, G.; NOVAIS, L. F.; CAGNIN, R. F. (Org.). A economia brasileira no contexto da crise global. São Paulo: Fundap, 2014. p. 51-78.

ROSSI, P.; MELLO, G. Componentes macroeconômicos e estruturais da crise brasileira: o subdesenvolvimento revisitado. Brazilian Keynesian Review, v. 2, n. 2, p. 252-263, 2016.

ROZAS, P.; SÁNCHEZ, R. Desarrollo de infraestructura y crecimiento económico: revisión conceptual. Santiago, Chile: ECLAC, 2004.

SECRETARIA DE POLÍTICA ECONÔMICA - SPE. Boletim do Resultado Fiscal Estrutural. Brasília: SPE, 2017.

SERRANO, F.; SUMMA, R. Demanda agregada e a desaceleração do crescimento econômico brasileiro de 2011 a 2014. Washington: Center for Economic and Policy Research - CPPR, 2015 .

TERRA, F. H. B.; FERRARI-FILHO, F. O papel do estado e a noção de desenvolvimento econômico em Keynes. In: FEIJÓ, C.; ARAUJO, E. C. (Org.). Macroeconomia moderna: lições de Keynes para economias em desenvolvimento. Rio de Janeiro: Elsevier, 2019. p. 33 44.

TERRA, F. H. B. A política fiscal na perspectiva pós-Keynesiana. FEIJÓ, C.; ARAUJO, E. C. (Org.). Macroeconomia moderna: lições de Keynes para economias em desenvolvimento. Rio de Janeiro: Elsevier, 2019. p. 57-68. 